DOI https://doi.org/10.30525/978-9934-26-046-9-22

\title{
MATHEMATICAL MODEL OF A LOADED SUPPORTING FRAME OF A SOLID FERTILIZERS DISTRIBUTOR
}

\author{
Dovbush T. A. \\ Candidate of Technical Sciences, Associate Professor, \\ Associate Professor at the Department of Technical Mechanics \\ and Agricultural Machinery \\ Ternopil Ivan Puluj National Technical University \\ Hevko R. B. \\ Doctor of Technical Sciences, \\ Professor at the Department of Technical Mechanics \\ and Agricultural Machinery \\ Ternopil Ivan Puluj National Technical University \\ Tson H. B. \\ Candidate of Technical Sciences, \\ Senior Lecturer at the Department of Technical Mechanics \\ and Agricultural Machinery \\ Ternopil Ivan Puluj National Technical University \\ Ternopil, Ukraine
}

The development of analytical methods of bearing complex structural systems calculating, simultaneously statically indeterminate relative to the external supports and internal force factors, taking into consideration the discrepancy in calculations and obtained experimental data requires the creation of new models of frame structures sresss-and-strain state (SSS) taking into account real loading [1;2].

SSS of frame structures by the finite element method comparing to the strain gauging has been studied in the paper [3]. The difference between calculations and research data is about $30-40 \%$.

The development of engineering methods of strength calculation and structural evaluation of agricultural machines supporting frames is one of the most important problems in their designing. A number of the abovementioned problems for certain design of agricultural machines or some of their elements (frames, sprayer booms sections and others) made of the rolled sections have been studied in the papers $[4 ; 5]$. 
In this case the conducted theoretical and experimental research [6-7] of root crops harvesters, different types of screw conveyors and their working tools has shown that it is necessary to conduct a complex of investigations to determine the optimal parameters of bearing structural members. The increase of their strength assurance factor causes the increase of the material consumption of machines and working tools structure and further increased energy consumption to perform a technological process and other negative consequences.

Some critical loads are taking place while a solid fertilizer loaded distributor is in operation and it is moving on the rough field surface with maximum translatory velocity causing fracture (cracks formation) of the bearing frame structure which is shown on Figure 1.

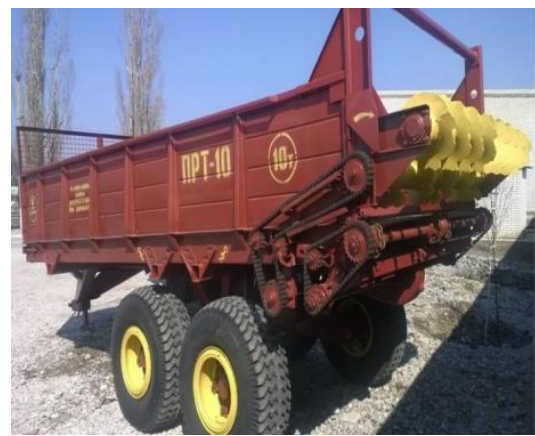

a
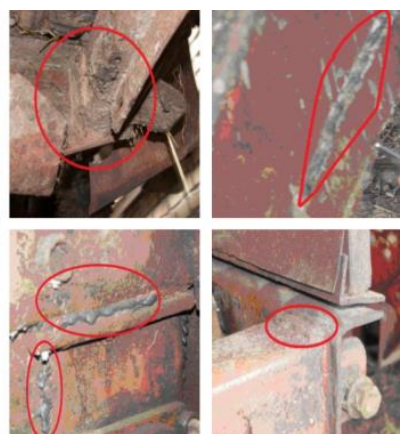

b

Figure 1. Main view of solid organic fertilizer distributor (a) and a place of cracks formation (b) taking place at maximal loading and moving on rough ground

Weight distribution of solid organic fertilizer on the distributor body space is mostly of variable form both in cross-section and longitudinal planes. Let's consider and classify the determining factors of unbalanced loading on the distributor body space (Figure 2a).

Figure 2a includes the following conventional signs: $q(s)$ - distributed load; $I, I I$ - lateral longerons of Z-like cross- section; $I I I$ - central longeron whose cross-section is made of two Z-like sections; $I V$ - travers (cross members) of pipelike cross-sections.

The supporting frame is divided into three parts in order to optimize the analytical calculations. The central part is conventionally designated as $I I I$, two symmetrical lateral parts are conventionally designated as $I$ i $I I$ (Figure 2a). 

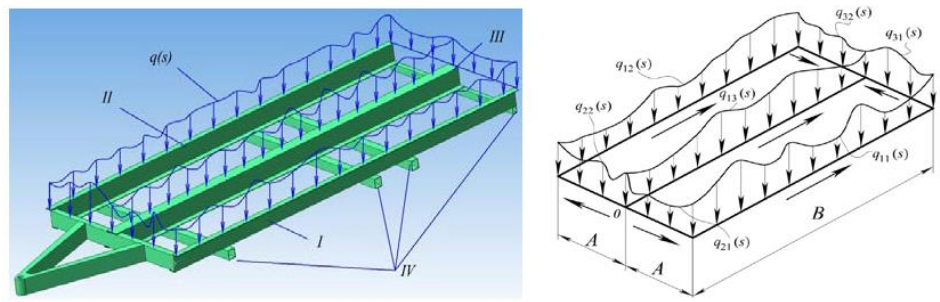

Figure 2. Schematization of supporting metalwork loading distribution of fertilizer distributor

Within the conditional symbols of geometric or physical parameters the first index indicates the geometric or physical magnitude order, the second one shows the section of the frame structure which the given magnitude belongs to.

Solid organic fertilizers are being loaded on the trailer body by a conveyor or a loader; their distribution is mostly nonuniform. Figure $2 b$ describes an arbitrary schematization of external loads distribution on the distributor supporting frames parts, $q_{11}(s), q_{21}(s), q_{31}(s), q_{12}(s)$, $q_{22}(s), q_{32}(s), q_{31}(s), q_{32}(s), q_{13}(s)$ are the functions of load intensity distributed on the frame supporting parts according to the directions shown on fig. $2 \mathrm{~b} ; A, B$ are geometric parameters of frame-body contact. General external loaing:

$$
Q_{0}=\sum_{i=1}^{n} \int_{0}^{l_{i}} q_{i}(s) d s=135000 N .
$$

A base frame is a complex framed supporting system, statically indeterminate. To evaluate the indeterminate expression of complex framed structures the modified method of minimum of potential energy of deformation (MMMPED) is the most efficient one as it considerably simplifies the solution of such problems and it is easily presented with algorithms. The main advantage of the method is that after writing the expression of potential energy of deformation as a function from unknown parameters $U(Q, M, K)$, which has an adaptive feature, we can use some constituents of energies depending upon a structural system and its loading [7]. The solution of obtained equations $d U / d X_{i}=0$ including the unknown pa- 
rameters $X_{i}$ is performed by means of application pragramme package (APP) Wolfram Mathematica 7.

Due to the obtained data we have built the distribution of the internal force factors in the structure (fig 3).

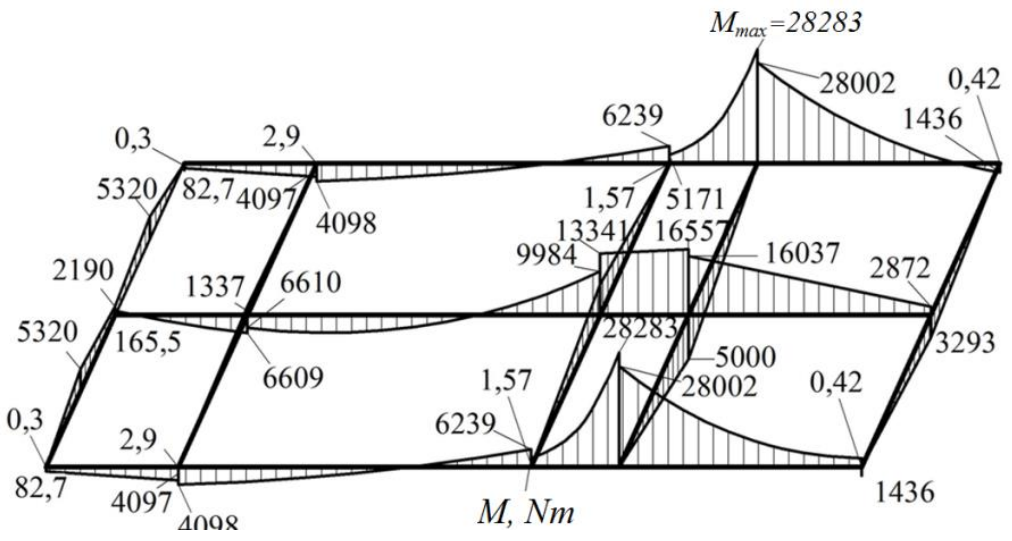

Figure 3. Distribution of the internal force factors of distributor frame loading

Conclusions A universal algorithm of additive functions writing of both bending and torque moments and potential energy of deformations as well taking into consideration the unknown values of external support reactions and the internal force factors has been composed. Some analytical research has been conducted including the substantiation of possible cases of external loading distribution along the perimeter of the machine under study (a supporting metalwork of a solid fertilizer distributor as a case of study). The efficiency of suggested approaches and models use at calculation of the supporting frame metalworks with arbitrary given distribution of external loading has been proved.

\section{References:}

1. Волков П.М. Основы теории и расчета сельскохозяйственных машин на прочность и надежность / под ред. П.М. Волкова, М.М. Тененбаума. М.: Машиностроение, 1977. 310 с.

2. Еременко С.Ю. Методы конечных элементов в механике деформируемых тел / С.Ю. Еременко. Харьков: Основа, 1991. 272 с. 
3. Вырский А.Н. Исследование нагруженности рамных конструкций / А.Н. Вырский / Тракторы и сельхозмашины. 1990. № 11. C. 26-27.

4. Довбуш Т.А., Довбуш А.Д., Хомик Н.І. Модифікація ММПЕД для розкриття статичної невизначеності криволінійних елементів рам. Технічний сервіс для машин для рослинництва. Х.: ХНТУСГ. 2014. Вип. 145. С. 105צ110.

5. Рибак Т.І., Попович П.В., Хомик Н.І., Довбуш Т.А., Цьонь Г.Б. Імітаційне моделювання при розрахунках на квазістатичну міцність конструктивних структур важко навантажених сільськогосподарських машин. Проблеми надійності машин та засобів механізації сільськогосподарського виробництва. Х.: ХНТУСГ. 2013. Вип. 139. C. 321-326.

6. Hevko R. B., Tkachenko R. I., Synii S. V., Flonts I. V. Development of design and investigation of operation processes of small-sclale root crop and potato harvesters. INMATEH: Agricultural engineering. Bucharest, Romania. 2016. Vol. 49. no. 2. P. 53-60.

7. Hevko B. M., Hevko R. B., Klendii O. M., Buriak M. V., Dzyadykevych Y. V. Improvement of machine safety devices. Acta Polytechnica. Czech Technical University in Prague. 2018. Vol. 58. № 1. P. 17-25. 